\title{
Analisis Efektivitas Biaya Penggunaan Antibiotik pada Pasien Community-acquired Pneumonia di RSUP Dr. Hasan Sadikin Bandung
}

\author{
Mia N. A. Fatin, Cherry Rahayu, Auliya A. Suwantika \\ Fakultas Farmasi, Universitas Padjadjaran, Sumedang, Indonesia
}

\begin{abstract}
Abstrak
Community-acquired Pneumonia (CAP) merupakan penyakit infeksi yang memiliki mortalitas, morbiditas dan biaya yang tinggi. Studi farmakoekonomi diperlukan untuk menganalisis pemilihan kombinasi antibiotik yang bervariasi dengan mempertimbangkan biaya dan efektivitas. Penelitian ini bertujuan untuk menganalisis nilai cost-effectiveness kombinasi antibiotik azitromisin-seftriakson dan kombinasi azitromisin-sefotaksim pada pengobatan CAP di RSUP Dr. Hasan Sadikin Bandung serta menganalisis faktor yang paling berpengaruh terhadap nilai cost-effectiveness. Pengumpulan data dilakukan secara retrospektif dari rekam medis pasien dan Sistem Informasi Rumah Sakit (SIRS). Penelitian ini dilakukan pada bulan Maret-Juni 2019. Data biaya meliputi total biaya medik dari rumah sakit/healthcare perspective (biaya obat, alat kesehatan, tindakan, pemeriksaan, jasa dokter, dan rawat inap) dan total biaya dari Badan Penyelenggara Jaminan Sosial (BPJS)/payer perspective (tarif INACBG). Nilai efektivitas pada penelitian ini diukur dalam penurunan jumlah leukosit. Hasil menunjukkan nilai Average Cost-effectiveness Ratio (ACER) pada kombinasi azitromisin-seftriakson dari payer dan healthcare perspective secara berturut-turut adalah Rp2.987 dan Rp2.080 per penurunan 1 sel leukosit/ $\mathrm{mm}^{3}$, lebih tinggi dibandingkan kombinasi azitromisin-sefotaksim yaitu Rp2.853 dan Rp1.184 per penurunan 1 sel leukosit $/ \mathrm{mm}^{3}$. Berdasarkan hasil perhitungan Incremental Cost-effectiveness Ratio (ICER), diketahui penggantian kombinasi azitromisin-seftriakson oleh azitromisin-sefotaksim akan menghemat biaya sebesar Rp4.531 (payer perspective) dan Rp22.379 (healthcare perspective). Hasil uji sensitivitas menunjukan penurunan leukosit dan biaya rawat inap memiliki rentang yang paling panjang. Kombinasi antibiotik azitromisin-sefotaksim lebih cost-effective dibandingkan azitromisin-seftriakson. Faktor yang paling memengaruhi nilai ICER adalah penurunan leukosit dan biaya rawat inap.
\end{abstract}

Kata kunci: ACER, analisis efektivitas biaya, CAP, ICER, leukosit

\section{Cost-effectiveness Analysis of Antibiotic of Patients with Community- acquired Pneumonia in Dr. Hasan Sadikin General Hospital Bandung}

\begin{abstract}
Community-acquired Pneumonia (CAP) is an infectious disease with high mortality, morbidity, and cost. A study of pharmacoeconomics is required to analyze the efficiency of various antibiotic combinations. This study aimed to investigate the cost-effectiveness values on the use of azithromycin-ceftriaxone and azithromycin-cefotaxime in the treatment of CAP at Dr. Hasan Sadikin General Hospital and to analyze the most influential factor impacting the cost-effectiveness value. Data collection was conducted retrospectively from the patient's medical record and the Hospital Information System (SIRS). This research was conducted in March-June 2019. The total medical costs were reviewed in the healthcare perspective (drug costs, medical devices, action costs, examination fees, doctor fees and the cost of hospitalization) and payer perspective (Social Security Administrator for Health, BPJS) (INA-CBG). The value of effectiveness was measured in the reduction of leukocytes. The results showed that the Average Cost-effectiveness Ratios (ACERs) of azithromycin-ceftriaxone from the payer and healthcare perspective in a row were 2.987 IDR and $2.080 \mathrm{IDR}$ per $1 \mathrm{cell} / \mathrm{mm}^{3}$ leukocytes reduction, higher than azithromycin-cefotaxime 2.853 IDR and 1.184 IDR per 1 cell $/ \mathrm{mm}^{3}$ leukocytes reduction. Based on the calculation of the Incremental Cost-effectiveness Ratio (ICER), if azithromycin-ceftriaxone is replaced by azithromycin-cefotaxime, it will save 4.531 IDR (payer perspective) and 22.379 IDR (healthcare perspective) per $1 \mathrm{cell} / \mathrm{mm}^{3}$ leukocytes reduction. It can be concluded that the combination of azithromycin-cefotaxime is more cost-effective than azithromycin-ceftriaxone. The reduction of leukocytes and the cost of hospitalization were the most influential parameters impacting the ICER.
\end{abstract}

Keywords: ACER, CAP, cost-effectiveness analysis, ICER, leukocytes

Korespondensi: Mia N. A. Fatin, M.Farm., Apt., Fakultas Farmasi, Universitas Padjadjaran, Sumedang, Jawa Barat 45363, Indonesia, e-mail: nisrinamia@gmail.com

Naskah diterima: 9 Juli 2019, Diterima untuk diterbitkan: 30 Agustus 2019, Diterbitkan: 28 September 2019 


\section{Pendahuluan}

Pneumonia merupakan penyakit infeksi pernafasan akut yang memengaruhi parenkim paru. ${ }^{1}$ Pada tahun 2018, prevalensi pneumonia di Indonesia mencapai 4\%. ${ }^{2}$ Berdasarkan tempat terjadinya infeksi, pneumonia diklasifikasikan menjadi pneumonia yang didapat di komunitas atau Community-acquired Pneumonia (CAP) dan pneumonia yang didapat di rumah sakit atau Hospital-acquired Pneumonia (HAP). ${ }^{1}$ Di Indonesia, CAP memiliki jumlah kasus yang lebih banyak dibandingkan HAP. ${ }^{3,4}$

CAP memiliki tingkat morbiditas maupun mortalitas yang tinggi. ${ }^{5-7}$ Biaya yang terkait dengan pengobatan CAP terhitung tinggi, ${ }^{8}$ yakni berkisar 254-1.208 USD di Indonesia. ${ }^{3}$ Penggunaan antibiotik yang memadai dapat membantu mengurangi biaya yang tinggi. ${ }^{9}$

Salah satu terapi antibiotik empiris untuk pengobatan pasien CAP non-ICU adalah kombinasi antibiotik betalaktam-makrolida. ${ }^{10}$ Tersedianya berbagai kombinasi antibiotik betalaktam-makrolida tersebut menyebabkan efektivitas maupun biaya yang diperlukan pun berbeda. Oleh karena itu, diperlukan analisis dari segi farmakoenomi yang melibatkan biaya dan efektivitas. Studi farmakoekonomi yang dilakukan pada penelitian ini adalah analisis efektivitas biaya yang memiliki tujuan untuk mengetahui kombinasi yang lebih costeffective antara azitromisin-seftriakson dan azitromisin-sefotaksim. Indikator kesehatan yang diukur adalah penurunan leukosit (1 sel leukosit $/ \mathrm{mm}^{3}$ ). Leukosit dapat menunjukkan outcome klinis pada pasien CAP karena peningkatan leukosit berhubungan dengan keparahan dan risiko kematian pada pasien pneumonia. ${ }^{11}$ Pada penelitian ini, perspektif yang digunakan adalah payer perspective (Badan Penyelenggara Jaminan Sosial/BPJS) dan healthcare perspective (rumah sakit). Selain itu, dilakukan analisis sensitivitas untuk mengetahui faktor yang paling berpengaruh terhadap nilai cost-effectiveness.

\section{Metode}

Penelitian ini telah mendapatkan izin etik dari Komisi Etik Penelitian Fakultas Kedokteran Universitas Padjadjaran Bandung (nomor 1506/ UN6/KEP/EC/2018) dan izin penelitian dari RSUP Dr. Hasan Sadikin Bandung (nomor LB.02.01/X.2.2.2/1886/2019). Pada penelitian ini, digunakan rancangan observasional crosssectional dengan pengambilan data secara retrospektif (Januari-Desember 2018). Teknik pengambilan sampel pada penelitian ini adalah total sampling. Pada total sampling, jumlah sampel sama dengan populasi terjangkau. ${ }^{12}$ Data diambil dari rekam medis pasien dan bagian Sistem Informasi Rumah Sakit (SIRS) RSUP Dr. Hasan Sadikin Bandung, meliputi data karakteristik pasien (nomor rekam medis, inisial pasien, umur, jenis kelamin), data klinis pasien (diagnosis, pemeriksaan leukosit), data penggunaan obat (dosis, aturan pakai, dan lama pemberian obat), data total biaya pengobatan (healthcare perspective: biaya tindakan, biaya pemeriksaan, biaya obat, biaya alat kesehatan, biaya rawat inap, biaya jasa dokter; payer perspective: tarif Indonesian-Case Based Groups/INA-CBG). Data leukosit yang diambil adalah rata-rata penurunan leukosit selama pasien dirawat.

Populasi target pada penelitian ini adalah seluruh pasien CAP di RSUP Dr. Hasan Sadikin Bandung dan populasi terjangkau adalah data rekam medis CAP di RSUP Dr. Hasan Sadikin Bandung pada periode Januari sampai Desember 2018. Kriteria inklusi pada penelitian ini adalah pasien rawat inap nonICU di RSUP Dr. Hasan Sadikin Bandung dengan diagnosis utama pasien CAP berusia $>18$ tahun, mendapatkan terapi kombinasi azitromisin-seftriakson dan azitromisinsefotaksim. Kriteria eksklusi pada penelitian ini adalah pasien tanpa jaminan kesehatan BPJS, meninggal/pulang paksa, mengalami pergantian antibiotik CAP, komorbid disertai penyakit infeksi yang lain, resisten terhadap 
azitromisin/seftriakson/sefotaksim, serta data yang tidak lengkap. Tingkat keparahan (severity) CAP tidak menjadi pertimbangan dalam pengambilan sampel. Seluruh pasien CAP yang memenuhi kriteria inklusi dan eksklusi dijadikan subjek penelitian. Ruang rawat pada penelitian ini hanya rawat inap non-ICU. Pengelompokan pada penelitian ini adalah kelompok A (azitromisin-seftriakson) dan kelompok B (azitromisin-sefotaksim). Perhitungan nilai cost-effectiveness (Average Cost-effectiveness Ratio/ACER dan Incremental Cost-effectiveness Ratio/ICER) menggunakan rumus berikut: ${ }^{13}$

$$
\text { ACER }=\frac{\text { Rata-rata total biaya }}{\text { Rata-rata efektivitas }}
$$

$$
\text { ICER }=\frac{\text { Biaya intervensi kel. A }- \text { kel. B }}{\text { Penurunan leukosit kel. A }- \text { kel. B }}
$$

Analisis sensitivitas dilakukan untuk mengetahui faktor yang paling berpengaruh terhadap nilai ICER, dengan menambahkan dan mengurangi $25 \%$ dari setiap parameter biaya dan efektivitas terhadap nilai ICER karena menggunakan triangular distribution dan dengan mempertimbangkan lower dan upper value $+/-25 \%$. Selain itu, pada studi analisis efektivitas biaya, dapat digunakan variasi $25 \% .^{13,14}$ Penambahan menjadi nilai upper limit dan pengurangan menjadi nilai lower limit. Hasil analisis lalu digambarkan dalam diagram tornado. Kemaknaan hasil uji ditentukan berdasarkan nilai $\mathrm{p}<0,05$. Uji statistik yang digunakan pada karakteristik subjek yaitu uji komparatif kategorik yakni Fisher's exact test dan Kolmogorov-Smirnov, sedangkan pada perbedaan biaya dan efektivitas digunakan uji komparatif numerik yaitu uji Mann-Whitney dan student t-test.

\section{Hasil}

Total pasien CAP non-ICU dengan usia $>18$ tahun di RSUP Dr. Hasan Sadikin Bandung pada bulan Januari sampai Desember 2018 berjumlah 203 pasien. Sebanyak 22 pasien (kelompok $\mathrm{A}=8$ pasien; kelompok $\mathrm{B}=14$ pasien) memenuhi kriteria inklusi. Alur pengambilan data dapat dilihat pada Gambar 1.

Subjek pada penelitian ini didominasi oleh pasien yang berusia usia $>60$ tahun. Jumlah subjek perempuan dan laki-laki berturut-turut adalah 59,1 \% dan 40,9\%. Ruangan inap kelas II dan III lebih banyak dalam subjek penelitian ini yaitu $90,9 \%$ dari total subjek. Jumlah komorbid terbanyak yaitu antara 0-2 komorbid. Rata-rata length of stay (LOS) dan length of stay antibiotic-related (LOSAR) pada kelompok A berturut-turut adalah 6,5 hari dan 5,9 hari, sedangkan pada kelompok B adalah 7,1 hari dan 5,4 hari (Tabel 1).

Nilai cost-effectiveness kelompok A dan B Total biaya yang diperlukan pada kelompok A adalah Rp9.914.513 (payer perspective) dan Rp6.903.169 (healthcare perspective), sedangkan total biaya pada kelompok B adalah Rp8.717.343 (payer perspective) dan Rp4227.714 (healthcare perspective). Kelompok A dapat menurunkan 3.320 sel leukosit $/ \mathrm{mm}^{3}$, lebih tinggi jika dibandingkan kelompok B yang dapat menurunkan 3.055 sel leukosit $/ \mathrm{mm}^{3}$ (Tabel 2).

Nilai ACER kelompok A dari payer dan healthcare perspective secara berturut-turut adalah Rp2.987 dan Rp2.080 per penurunan 1 sel leukosit $/ \mathrm{mm}^{3}$, sedangkan kelompok B adalah Rp2.853 dan Rp 1.184 per penurunan 1 sel leukosit $/ \mathrm{mm}^{3}$. Hasil perhitungan ICER $\mathrm{B}_{\mathrm{B} \rightarrow \mathrm{A}}$ baik dari payer maupun healthcare perspective berturut-turut adalah Rp4.531 dan Rp22.379 (Tabel 3).

\section{Analisis sensitivitas}

Hasil analisis sensitivitas akan menunjukkan lower limit yaitu ICER-25\% dan upper limit yaitu ICER $+25 \%$. Semakin panjang rentang /besar selisih antara lower dan upper limit artinya semakin besar pengaruhnya terhadap nilai ICER. Parameter yang memiliki rentang 


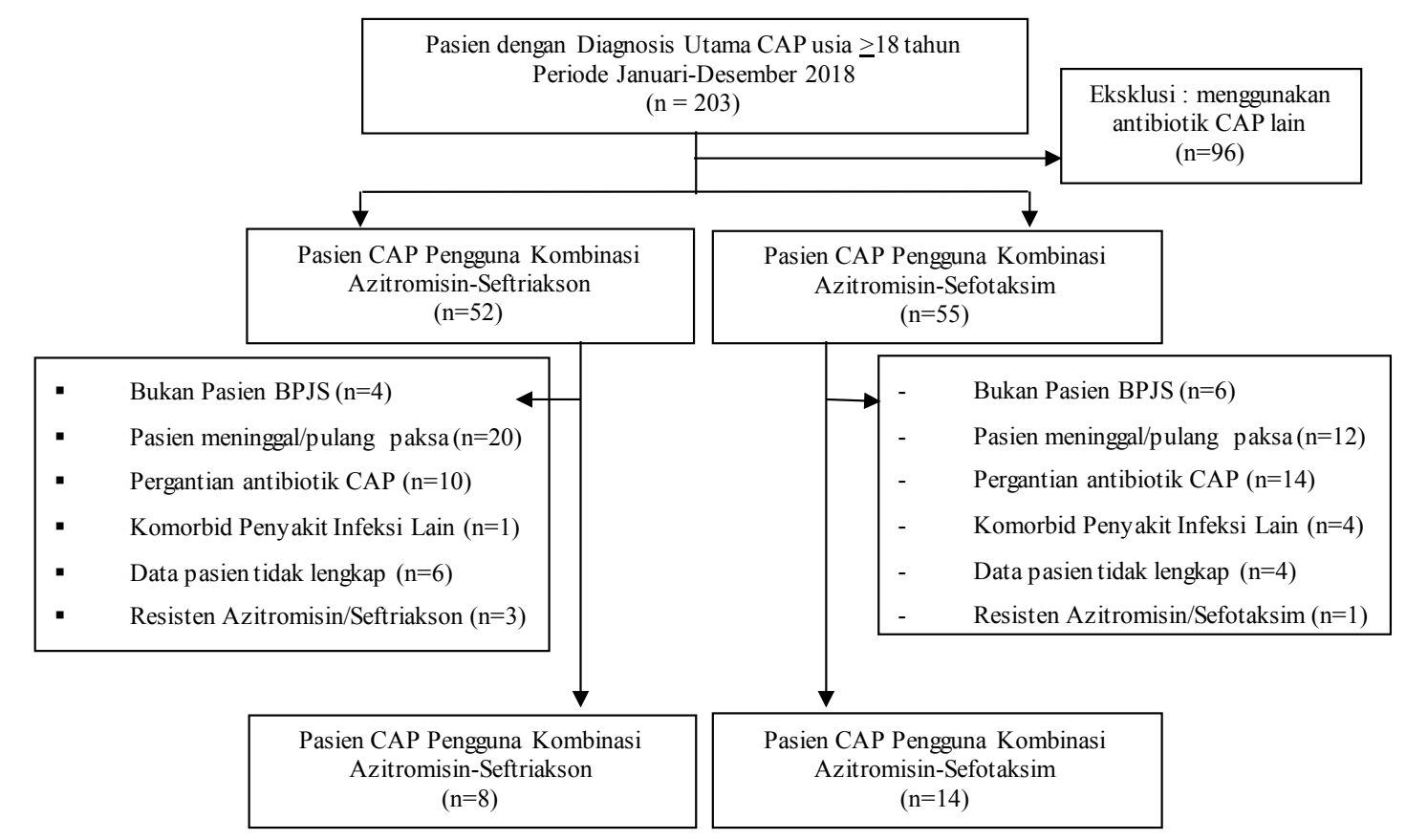

\section{Gambar 1 Alur Pengambilan Data}

terpanjang/selisih terbesar adalah penurunan leukosit dan biaya rawat inap (Tabel 4). Selanjutnya, dapat dilihat bahwa parameter yang berada paling atas adalah penurunan leukosit dan biaya rawat inap (Gambar 2).

\section{Pembahasan}

Kombinasi betalaktam-makrolida merupakan salah satu terapi antibiotik empiris pada CAP non-ICU. ${ }^{10}$ Penambahan makrolida (azitromisin) pada betalaktam (seftriakson atau sefotaksim) dapat meningkatkan efektivitas dibandingkan hanya betalaktam saja. ${ }^{15}$ Hal tersebut karena makrolida memiliki efek imunomodulator pada sel epitel. ${ }^{16}$ Kombinasi betalaktam-makrolida (azitromisin-seftriakson dan azitromisinsefotaksim) merupakan kombinasi antibiotik yang paling banyak digunakan di RSUP Dr. Hasan Sadikin pada pasien CAP non-ICU.

Tidak ditemukan perbedaan yang signifikan antara karakteristik subjek kelompok A dan kelompok B. Persentase terbanyak dalam subjek penelitian ini merupakan pasien yang berusia $>60$ tahun. Hal tersebut disebabkan pneumonia lebih sering menyerang lansia. ${ }^{17,18}$
Pasien CAP yang dirawat di rumah sakit paling banyak adalah pasien usia $>60$ tahun. ${ }^{19}$ Di Vietnam, insiden CAP pada pasien usia $>75$ tahun mencapai 6,95 per 1.000 jiwa/tahun, ${ }^{20}$ sedangkan di Thailand, insiden CAP pada pasien $>70$ tahun mencapai 1,5 per 1.000 jiwa/tahun. ${ }^{21}$ Di Spanyol dan Jerman, insiden CAP yang terjadi pada pasien usia $>65$ tahun mencapai 76-140 kasus per jiwa/tahun. ${ }^{22,23}$

LOS subjek penelitian ini terbanyak berada pada rentang 6-10 hari. Hasil studi ini serupa dengan penelitian di Indonesia, Malaysia dan Filipina, yaitu rata-rata LOS secara berturutturut adalah 6,1, 8,6 dan 6,2 hari. $^{3}$

LOSAR merupakan jumlah hari pasien mengonsumsi antibiotik. Rata-rata LOSAR pada kelompok A dan B berturut-turut adalah 5,9 dan 5,4 hari. Penelitian lain di Indonesia menyatakan LOSAR pada pasien CAP yang menggunakan azitromisin-seftriakson adalah 6 hari. ${ }^{24}$ LOSAR yang direkomendasikan yaitu $>5$ hari. ${ }^{25}$

Nilai cost-effectiveness kelompok A dan B Rata-rata penurunan leukosit pada kedua kelompok tidak berbeda signifikan, meskipun 
Tabel 1 Data Karakteristik Subjek Penelitian

\begin{tabular}{|c|c|c|c|c|}
\hline Karakteristik & $\begin{array}{c}\text { Kelompok A } \\
(\mathrm{n}=8)(\mathrm{n},(\%))\end{array}$ & $\begin{array}{c}\text { Kelompok B } \\
(n=14)(n,(\%))\end{array}$ & $\begin{array}{c}\text { Total } \\
(n=22)(n,(\%))\end{array}$ & Nilai $p$ \\
\hline \multicolumn{5}{|l|}{ Usia (tahun) } \\
\hline $18-39$ & $1(12,5)$ & $3(21,4)$ & $4(18,2)$ & $1,000^{\mathrm{b}}$ \\
\hline $40-59$ & $1(12,5)$ & $2(14,3)$ & $3(13,6)$ & \\
\hline$>60$ & $6(75,0)$ & $9(64,3)$ & $15(68,2)$ & \\
\hline \multicolumn{5}{|l|}{ Jenis Kelamin } \\
\hline Perempuan & $4(50,0)$ & $9(64,3)$ & $13(59,1)$ & $0,662^{\mathrm{a}}$ \\
\hline Laki-laki & $4(50,0)$ & $5(35,7)$ & $9(40,9)$ & \\
\hline \multicolumn{5}{|l|}{ Jaminan Pembiayaan } \\
\hline BPJS non-PBI & $5(62,5)$ & $11(78,6)$ & $16(72,7)$ & $0,624^{\mathrm{a}}$ \\
\hline BPJS PBI & $3(37,5)$ & $3(21,4)$ & $6(27,3)$ & \\
\hline \multicolumn{5}{|l|}{ Jenis Kamar Rawat Inap } \\
\hline Kelas I dan VIP & $1(12,5)$ & $1(7,1)$ & $2(9,1)$ & $1,000^{\mathrm{a}}$ \\
\hline Kelas II dan III & $7(87,5)$ & $13(92,9)$ & $20(90,9)$ & \\
\hline \multicolumn{5}{|l|}{ Jumlah Komorbid } \\
\hline $0-2$ & $6(75,0)$ & $11(78,6)$ & $17(77,3)$ & $1,000^{\mathrm{a}}$ \\
\hline$>2$ & $2(25,0)$ & $3(21,4)$ & $5(22,7)$ & \\
\hline \multicolumn{5}{|l|}{ LOS (hari) } \\
\hline $1-5$ & $3(37,5)$ & $2(14,3)$ & $5(22,7)$ & $0,947^{\mathrm{b}}$ \\
\hline $6-10$ & $4(50,0)$ & $12(85,7)$ & $16(72,7)$ & \\
\hline$>1$ & $1(12,5)$ & $0(0,0)$ & $1(4,5)$ & \\
\hline Rata-rata+SD & $6,5+2,5$ & $7,1+2,1$ & $6,9+2,2$ & \\
\hline \multicolumn{5}{|l|}{ LOSAR (hari) } \\
\hline $1-5$ & $4(50,0)$ & $7(50,0)$ & $11(50,0)$ & $1,000^{\mathrm{a}}$ \\
\hline $6-10$ & $4(50,5)$ & $7(50,0)$ & $11(50,0)$ & \\
\hline Rata-rata+SD & $5,9+2,0$ & $5,4+1,6$ & $5,6+1,7$ & \\
\hline
\end{tabular}

Keterangan: $\mathrm{p}>0,05=$ perbedaan tidak signifikan; $\mathrm{a}=$ Fisher's exact test; $\mathrm{b}=$ uji Kolmogorov-Smirnov; $\mathrm{PBI}=$ Penerima Bantuan Iuran; LOS=Length of stay; LOSAR=Length of stay antibiotic-related

kelompok A dapat menurunkan sel leukosit lebih banyak jika dibandingkan kelompok B. Hal ini menunjukkan bahwa baik kombinasi azitromisin-seftriakson maupun kombinasi azitromisin-sefotaksim keduanya memiliki efek yang baik terhadap outcome klinis pasien
CAP. Seftriakson dan sefotaksim merupakan antibiotik golongan sefalosporin generasi tiga dengan spektrum yang mirip, tetapi perbedaannya terdapat di ikatan protein dan waktu paruh, yaitu seftriakson memiliki ikatan protein $85-95 \%$ dan waktu paruh 5-9 jam,

Tabel 2 Parameter Biaya dan Efektivitas

\begin{tabular}{lccc}
\hline \multicolumn{1}{c}{ Parameter } & Kelompok A $(\mathbf{n}=\mathbf{8})$ & Kelompok B $(\mathbf{n = 1 4})$ & Nilai $\mathbf{~}$ \\
\hline Biaya Tindakan & Rp680.781 & Rp331.942 & $0,274^{\mathrm{a}}$ \\
Biaya Pemeriksaan & Rp283.750 & Rp297.143 & $0,864^{\mathrm{a}}$ \\
Biaya Alkes & Rp316.838 & Rp539.900 & $0,495^{\mathrm{a}}$ \\
Biaya Obat & $\mathrm{Rp} 1.106 .050$ & $\mathrm{Rp} 751.086$ & $0,838^{\mathrm{a}}$ \\
Biaya Rawat Inap & $\mathrm{Rp} 3.894 .500$ & $\mathrm{Rp} 2.105 .143$ & $0,181^{\mathrm{a}}$ \\
Biaya Jasa Dokter & $\mathrm{Rp} 621.250$ & $\mathrm{Rp} 4.227 .714$ & $0,140^{\mathrm{a}}$ \\
Total Biaya (healthcare) & $\mathrm{Rp} 6.903 .169$ & $\mathrm{Rp} 8.717 .343$ & $0,351^{\mathrm{a}}$ \\
Total Biaya (payer) & $\mathrm{Rp} 9.914 .513$ & $3.055 \mathrm{sel} / \mathrm{mm}^{3}$ & $0,339^{\mathrm{a}}$ \\
Penurunan Leukosit & $3.320 \mathrm{sel} / \mathrm{mm}^{3}$ & $0,787^{\mathrm{b}}$ \\
\hline
\end{tabular}

Keterangan: $\mathrm{p}>0,05=$ perbedaan tidak signifikan; a=uji Mann-Whitney; $\mathrm{b}=\mathrm{uji} \mathrm{t}$ 
Tabel 3 Nilai ACER dan ICER dari Dua Perspektif

\begin{tabular}{|c|c|c|c|c|c|c|c|c|}
\hline \multirow{2}{*}{\multicolumn{2}{|c|}{ Kelompok }} & \multicolumn{2}{|c|}{$\begin{array}{c}\operatorname{ACER}(\mathrm{C} / \mathrm{E}), \\
\left(\mathrm{Rp} / 1 \mathrm{sel} / \mathrm{mm}^{3}\right)\end{array}$} & \multicolumn{2}{|c|}{$\begin{array}{l}\text { Total Biaya Medik } \\
\text { (C), (Rp) }\end{array}$} & \multicolumn{2}{|c|}{$\begin{array}{l}\operatorname{ICER}_{\mathrm{B} \rightarrow \mathrm{A}} \\
(\mathrm{Rp})\end{array}$} & \multirow{2}{*}{$\begin{array}{c}\text { Penurunan } \\
\text { Leukosit (E), } \\
\left(\mathrm{sel} / \mathbf{m m}^{3}\right)\end{array}$} \\
\hline & & Payer & Healthcare & Payer & Healthcare & Payer & Healthcare & \\
\hline A & $\begin{array}{l}\text { Azitromisin- } \\
\text { Seftriakson }\end{array}$ & 2.987 & 2.080 & 9.914 .513 & 6.903 .169 & 4531 & 22379 & 3.320 \\
\hline B & $\begin{array}{l}\text { Azitromisin- } \\
\text { Sefotaksim }\end{array}$ & 2.853 & 1.184 & 8.717 .343 & 4.227 .714 & 4.531 & $22.3 / 9$ & 3.055 \\
\hline
\end{tabular}

Tabel 4 Hasil Uji Sensitivitas

\begin{tabular}{lccc}
\hline \multicolumn{1}{c}{ Parameter } & Lower Limit (ICER-25\%) & Upper Limit (ICER+25\%) & Selisih \\
\hline Penurunan Leukosit & 29.838 & 17.903 & 11.935 \\
Biaya Rawat Inap & 18.637 & 26.120 & 7.483 \\
Biaya Jasa Dokter & 21.503 & 23.254 & 1.751 \\
Biaya Obat & 21.636 & 23.121 & 1.485 \\
Biaya Tindakan & 21.649 & 23.108 & 1.459 \\
Biaya Alkes & 22.845 & 21.912 & 933 \\
Biaya Pemeriksaan & 22.407 & 22.351 & 56 \\
\hline
\end{tabular}

sedangkan sefotaksim $40 \%$ dan $1-1,5$ jam. ${ }^{26,27}$ Oleh karena itu, seftriakson digunakan dua kali sehari, sedangkan sefotaksim tiga kali sehari. Dosis obat pada penelitian ini adalah azitromisin 1x500 mg per oral, seftriakson $2 \mathrm{x} 1 \mathrm{~g}$ intravena, dan sefotaksim $3 \times 1 \mathrm{~g}$ intravena.

Total biaya yang dibutuhkan (payer dan healthcare perspective) oleh kedua kelompok tidak memiliki perbedaan yang signifikan meskipun kelompok A membutuhkan biaya yang lebih tinggi jika dibandingkan kelompok B. Dalam total biaya (healthcare perspective), persentase terbesar digunakan untuk biaya rawat inap. Hasil serupa menyebutkan bahwa biaya rawat inap menjadi biaya yang paling besar dibandingkan biaya lainnya. ${ }^{28}$

Kelompok B memiliki nilai ACER (payer dan healthcare perspective) yang lebih rendah. Semakin rendah ACER, maka terapi tersebut semakin cost-effective. ${ }^{13}$ Oleh karena itu, azitromisin-sefotaksim lebih cost-effective dibandingkan dengan azitromisin-seftriakson, meskipun secara statistik tidak ada perbedaan yang signifikan. Hasil serupa dalam penelitian lain juga menyebutkan bahwa azitromisinsefotaksim lebih cost-effective dibandingkan

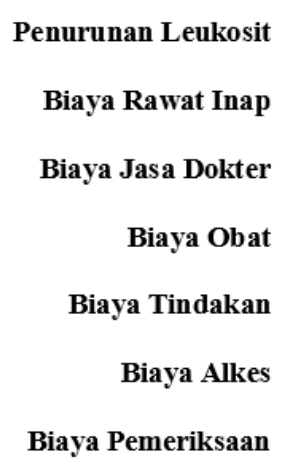

Gambar 2 Uji Sensitivitas

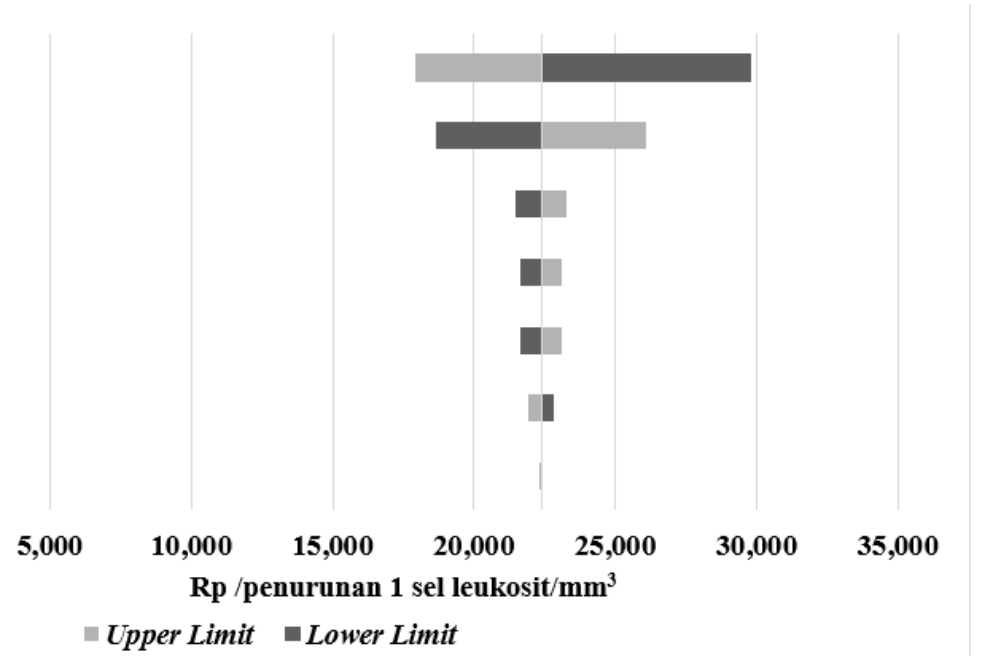


azitromisin-seftriakson..$^{29}$ Hasil penelitian ini menunjukkan bahwa meskipun efektivitas kombinasi azitromisin-seftriakson lebih tinggi dibandingkan azitromisin-sefotaksim, tidak berarti bahwa azitromisin-seftriakson lebih cost-effective sebab diperlukan biaya yang lebih tinggi.

Berdasarkan hasil perhitungan nilai ICER, kombinasi antibiotik azitromisin-sefotaksim apabila menggantikan kombinasi azitromisinseftriakson akan dapat menghemat biaya yaitu sebesar Rp4.531 (payer perspective) dan Rp22.379 (healthcare perspective). Dilihat dari nilai ICER healthcare perspective yang lebih tinggi dibandingkan payer perspective, maka rumah sakit akan lebih banyak menghemat dibandingkan BPJS. Hal tersebut akan lebih bermanfaat dan menguntungkan bagi rumah sakit.

\section{Analisis sensitivitas}

Pada diagram hasil uji sensitivitas, bar yang paling atas dan rentangnya paling panjang merupakan faktor yang paling berpengaruh. Penurunan leukosit dan biaya rawat inap merupakan faktor yang paling berpengaruh terhadap nilai ICER dan keduanya memiliki keterkaitan. Semakin baik penurunan leukosit, semakin cepat pula proses pemulihan pasien sehingga biaya rawat inap dapat berkurang. Efektivitas terapi merupakan faktor yang memengaruhi dan memiliki peran penting dalam penentuan efektivitas biaya antibiotik. ${ }^{30}$

Keterbatasan penelitian ini adalah jumlah sampel yang sedikit disebabkan banyaknya jenis antibiotik yang digunakan oleh pasien CAP di RSUP Dr. Hasan Sadikin Bandung, sehingga penggunaan jenis antibiotik yang sedikit pada pasien masuk ke dalam kriteria eksklusi dan hanya pasien yang menggunakan jenis antibiotik terbanyak saja yang menjadi subjek penelitian, yaitu kombinasi azitromisinseftriakson dan azitromisin-sefotaksin. Perlu dilakukan penelitian lebih lanjut mengenai jenis antibiotik lainnya.

\section{Simpulan}

Tidak ada perbedaan yang signifikan pada efektivitas (penurunan leukosit) dan total biaya medik antara kombinasi azitromisinseftriakson dan azitromisin-sefotaksim, meskipun nilai ACER azitromisin-sefotaksim lebih rendah jika dibandingkan azitromisinseftriakson. Berdasarkan hasil uji analisis sensitivitas, penurunan leukosit dan biaya rawat inap merupakan faktor yang paling berpengaruh terhadap nilai ICER.

\section{Pendanaan}

Penelitian ini tidak didanai oleh sumber hibah manapun.

\section{Konflik Kepentingan}

Seluruh penulis menyatakan tidak terdapat potensi konflik kepentingan dengan penelitian, kepenulisan (authorship), dan atau publikasi artikel ini.

\section{Daftar Pustaka}

1. Bartolf A, Cosgrove C. Pneumonia. Medicine (Baltimore). 2016;44(6):3737. doi: 10.1016/j.mpmed.2016.03.004

2. Kementerian Kesehatan Republik Indonesia. Riset kesehatan dasar 2018. Jakarta: Kementerian Kesehatan Republik Indonesia; 2018.

3. Azmi S, Aljunid SM, Maimaiti N, Ali AA, Muhammad Nur A, De Rosas-Valera M, et al. Assessing the burden of pneumonia using administrative data from Malaysia, Indonesia, and the Philippines. Int J Infect Dis. 2016;49:87-93. doi:10.1016/j.ijid.20 16.05.021

4. Wiersinga WJ, Bonten MJ, Boersma WG, Jonkers RE, Aleva RM, Kullberg BJ, et al. SWAB/NVALT (Dutch Working Party on Antibiotic Policy and Dutch Association 
of Chest Physicians) guidelines on the management of community-acquired pneumonia in adults. Neth J Med. 2012; 70(2):90-101.

5. Prina E, Ranzani OT, Torres A. Communityacquired pneumonia. Lancet. 2015;386 (9998):1-25. doi: 10.1016/S0140-6736(1 5)60733-4

6. Wunderink RG, Waterer GW. Communityacquired pneumonia. N Engl J Med. 2014; 370(6):543-51. doi: 10.1056/NEJMcp12 14869

7. Murray CJL, Lopez AD. Measuring the global burden of disease. N Engl J Med. 2013;369(5):448-57. doi: 10.1056NEJMr a1201534

8. Welte T, Torres A, Nathwani D. Clinical and economic burden of communityacquired pneumonia among adults in Europe. Thorax. 2012;67(1):71-9. doi: 10. 1136/thx.2009.129502

9. Carratala J, Garcia-Vidal C, Ortega L, Fernández-Sabé N, Clemente $M$, Albero G, et al. Effect of a 3-step critical pathway to reduce duration of intravenous antibiotic therapy and length of stay in community-acquired pneumonia: A randomized controlled trial. Arch Intern Med. 2012;172(12):922-8. doi: 10.1001/ archinternmed.2012.1690

10. Postma DF, van Werkhoven $\mathrm{CH}$, van Elden LJR, Thijsen SFT, Hoepelman AIM, Kluytmans JAJW, et al. Antibiotic treatment strategies for communityacquired pneumonia in adults. $\mathrm{N}$ Engl $\mathrm{J}$ Med. 2015;372(14):1312-23. doi: 10.105 6/NEJMoa1406330

11. Blot M, Croisier D, Péchinot A, Vagner A, Putot A, Fillion A, et al. A leukocyte score to improve clinical outcome predictions in bacteremic pneumococcal pneumonia in adults. Open forum Infect Dis. 2014;1(2):ofu075. doi: 10.1093/ofid /ofu075

12. Sugiyono P. Metodologi penelitian kuantitatif kualitatif dan R\&D. Bandung: Alpabeta; 2011.

13. Kementerian Kesehatan Republik Indonesia. Pedoman penerapan kajian farmakoekonomi. Jakarta: Kementerian Kesehatan Republik Indonesia; 2013.

14. Murphy G, Farah B, Wong W, Krahn M, Wells G, Chen L, et al. Direct-acting antiviral agents for chronic hepatitis $\mathrm{c}$ genotype 1. Ottawa (ON): Canadian Agency for Drugs and Technologies in Health, CADTH Therapeutic Reviews; 2014.

15. Nie W, Li B, Xiu Q. $\beta$-Lactam/macrolide dual therapy versus $\beta$-lactam monotherapy for the treatment of community-acquired pneumonia in adults: A systematic review and meta-analysis. J Antimicrob Chemother. 2014;69(6):1441-6. doi: 10.1093/jac/dku 033

16. Emmet O'Brien M, Restrepo MI, MartinLoeches I. Update on the combination effect of macrolide antibiotics in community-acquired pneumonia. Respir Investig. 2015;53(5):201-9. doi: 10.1016/ j.resi nv.2015.05.003

17. Stupka JE, Mortensen EM, Anzueto A, Restrepo MI. Community-acquired pneumonia in elderly patients. Aging Health. 2009;5(6):763-74. doi: 10.2217/ ahe.09.74

18. Rozenbaum MH, Mangen M-JJ, Huijts SM, van der Werf TS, Postma MJ. Incidence, direct costs and duration of hospitalization of patients hospitalized with community acquired pneumonia: A nationwide retrospective claims database analysis. Vaccine. 2015;33(28):3193-9. doi: 10.1016/j.vaccine. 2015.05 .001

19. Kolditz M, Tesch F, Mocke L, Hoffken G, Ewig S, Schmitt J. Burden and risk factors of ambulatory or hospitalized CAP: A population based cohort study. Respir Med. 2016;121:32-8. doi: 10.1016/j.rme d.2016.10.015

20. Takahashi K, Suzuki M, Minh LN, Anh 
NH, Huong LTM, Son TVV, et al. The incidence and aetiology of hospitalised community-acquired pneumonia among Vietnamese adults: A prospective surveillance in Central Vietnam. BMC Infect Dis. 2013;13:296. doi: 10.1186/147 1-2334-13-296

21. Piralam B, Tomczyk SM, Rhodes JC, Thamthitiwat S, Gregory CJ, Olsen SJ, et al. Incidence of pneumococcal pneumonia among adults in rural thailand, 20062011: Implications for pneumococcal vaccine considerations. Am J Trop Med Hyg. 2015;93(6):1140-7. doi:10.4269/ajt mh.15-0429

22. Ewig S, Birkner N, Strauss R, Pauletzki J, Bischoff H, Schraeder P, et al. New perspectives on community-acquired pneumonia in 388406 patients. Results from a nationwide mandatory performance measurement programme in healthcare quality. Thorax. 2009;64(12):1062-9. doi: 10.1136/thx.2008.109785

23. Vila-Corcoles A, Ochoa-Gondar O, Rodriguez-Blanco T, Raga-Luria $\mathrm{X}$, Gomez-Bertomeu F; EPIVAC Study Group. Epidemiology of communityacquired pneumonia in older adults: A population-based study. Respir Med. 2009; 103(2):309-16. doi: 10.1016/j.rmed.200 8.08 .006

24. Suratini S, Sauriasari R, Hamadah F. Cost-effectiveness analysis of ceftriaxoneazithromycin combination and single levofloxacin as empirical antibiotics in community-acquired pneumonia inpatients at persahabatan hospital. Asian J Pharm Clin Res. 2017;10(5):118-23. doi: 10.2215 9/ajpcr.2017.v10s5.23112

25. Wiersinga WJ, Bonten MJM, Boersma WG, Jonkers RE, Aleva RM, Kullberg $\mathrm{BJ}$, et al. Management of communityacquired pneumonia in adults: 2016 guideline update from the Dutch Working Party on Antibiotic Policy (SWAB) and Dutch Association of Chest Physicians (NVALT). Neth J Med. 2018;76(1):4-13. 26. Ulldemolins M, Roberts JA, Rello J, Paterson DL, Lipman J. The effects of hypoalbuminaemia on optimizing antibacterial dosing in critically ill patients. Clin Pharmacokinet. 2011;50(2):99-110. doi: 10.2165/11539220-000000000-00000.

27. American Pharmacists Association. Drug information handbook: A comprehensive resource for all clinicians and healthcare professionals. Riverwoods: Lexi-Comp; 2012.

28. Ruterlin V, Sinuraya RK, Halimah E, Barliana MI, Hartini S. Economic evaluation of the use of cefotaxime and ceftazidime in the treatment of pneumonia in pediatric patients. Pharmacol Clin Pharm Res. 2017;2(1):17-21. doi: 10.154 16/pcpr.v2i1.15741

29. Khan IA, R.H Rani S, Subramanyam G, Dsa S. Efficacy and safety of azithromycin with various cephalosporins used in treatment of lower respiratory tract infection. Indian J Pharm Pract. 2009;1 (2):53-61.

30. Simoens S. Factors affecting the cost effectiveness of antibiotics. Chemother Res Pract. 2011;2011:249867. doi: 10.115 $5 / 2011 / 249867$ 